\title{
Local snake fruit conservation in East Java, Indonesia: Community knowledge and appreciation
}

\author{
NOVITA K. INDAH ${ }^{1,2, \boldsymbol{}}$, SERAFINAH INDRIYANI ${ }^{1}$, ESTRI LARAS ARUMINGTYAS $^{\mathbf{1}}$, \\ RODIYATI AZRIANINGSIH ${ }^{1}$ \\ ${ }^{1}$ Department of Biology, Faculty of Mathematics and Natural Sciences, Universitas Brawijaya. Jl. Veteran, Malang 65415, East Java, Indonesia \\ ${ }^{2}$ Department of Biology, Faculty of Mathematics and Natural Sciences, Universitas Negeri Surabaya. J1. Ketintang, Surabaya 60231, East Java, \\ Indonesia. Tel./fax.: +62-31-8280009, `email: novitakartika@unesa.ac.id.
}

Manuscript received: 19 November 2020. Revision accepted: 28 December 2020.

\begin{abstract}
Indah NK, Indriyani S, Arumingtyas EL, Azrianingsih R. 2021. Local snake fruit conservation in East Java, Indonesia: Community knowledge and appreciation. Biodiversitas 22: 416-423. The community-based conservation of plant species diversity by variety of utility is an effective method for preserving local plants. Salak or the 'snake fruit' from East Java is an important fruit plant species in East Java. However, recent dramatic decline in its production and consumption occurred due to land-use change of plantation into resident or settlement areas. This study aims to analyze the value of local knowledge and appreciation and discusses the conservation strategy to cope with the situation. This descriptive research adopted 328 respondents from 10 local and introduced snake fruit cultivation areas in East Java. Respondents were divided into four age categories: young (17-30 years), adults (30-45 years), middle-aged (45-60 years), and old (>60 years). The questioner consisted of closed and open questions about knowledge (9 questions) and appreciation (13 questions). There were variations in the level of knowledge and appreciation between locations and ages. The highest appreciation about snake fruit utilization was shown by the middle-aged group ( $85.53 \%$ and $75 \%$ respectively) based on the age group. In comparison, the lowest scores were shown in the young group (79.82\% and $59.80 \%$ respectively). The points that support appreciation such as benefits and value of snake fruit for societal support. Based on the snake fruit cultivation area, the highest score for knowledge and appreciation of its value was found in Bojonegoro (98.1\% and $87.01 \%$ respectively) while these were the lowest in Trenggalek (68.0\% and $57.10 \%$ respectively). Appreciation supports community-based conservation through snake fruit festivals, product diversification i.e. making processed foods, and its use in religious ceremonies.
\end{abstract}

Keywords: Appreciation, biodiversity, genetic resources community, conservation, perception

\section{INTRODUCTION}

Preservation of traditional knowledge and practices is believed to have an important role in maintaining wild and multipurpose plants and conserving genetic resources in situ through sustainable use (Tura et al. 2017). The ethnobotanical study is one approach to preserve traditional knowledge through documentation and research activities. The study of the potential and characteristics of local flora provides important information for utilization and prevention from extinction. One form of study to document traditional knowledge is carried out by studying perceptions and appreciation of local community on preserving local plant. The role of the community is substantial in the preservation of natural resources including local flora (Russell et al. 2015). Conservation of local flora, especially native fruit plants, can be done through sustainable use and domestication. Domestication of various types of fruit trees is generally carried out in the yard or home garden. Several studies on the fruit plant species in the yard or home garden showed that Indonesia has great potential. Previous studies in Aceh Tamiang District reported 39 species of fruit plants (Elfrida et al. 2020); in South Aceh District there were 56 species of native edible fruit plants (Suwardi et al. 2020), while in Karo District there were 30 species of fruit plant (Silalahi and Nisyawati 2018). This species of native fruit plant plays an important role in the daily life of people living in developing countries, including in cultural events (Mabaya et al. 2014; Khruomo and Deb 2018; Sutraningsih 2019; Purwanto 2020). In Indonesia, several types of fruit are used in traditional ceremonial events, such as Sekaten in Yogyakarta (Widiyastuti et al 1998), sea picking in Banyuwangi (Purwanto 2020), Daksina events in Bali (Sutraningsih 2019), and okay soup ceremony in Halmahera (Wakhidah et al. 2017).

Among native fruit plant species to Indonesia, salak or snake fruit has been domesticated and cultivated in several locations such as Jakarta, West Java, Central Java, Yogyakarta, and East Java (Henderson 2008; Dransfield 2009). Snake fruit has widely distributed in Myanmar, the Malay Peninsula, Thailand, and the Philippines. This species has been introduced to Papua New Guinea, Australia (Queensland, and northern Australia), Suriname, Spain, and Fiji (Saleh et al. 2018). In Indonesia, snake fruit is popular because of its sweet and crunchy taste. The fruit contains proteins, carbohydrates, calcium, phosphorus, iron, vitamin ( $\mathrm{B}, \mathrm{C}$ and $\mathrm{E}), \beta$ carotene, lycopene, tannins, potassium, monoterpenoids, flavonoids, and a few other minerals (Suica-Bunghez et al. 2016).

Utilization of snake fruit by the community has positive impacts on economy and socio-culture sustainability. Large 
quantities of the fruit have been traded both as fresh fruit and as processed products such as chips. Until now, ethnobotany data and information on the intensity and diversity of the use of snake fruit by the community are few. This ethnobotanical knowledge is a very important document to show the close relation of the local community to the snake fruit plant. Their knowledge of and appreciation of the fruit can help understand local plant conservation practices and the possible applications in larger conservation programs. Therefore, it is important to explore cultural diversity and document it to preserve its traditional knowledge (Jaisankar et al. 2018).

Research on ethnobotany is mostly conducted on medicinal plants (Awoyemi et al. 2012; Ahmad et al. 2014; Kantati et al. 2016). Research efforts on medicinal plants are aimed at conducting bioprospection and utilization for disease prevention and treatment. Apart from medicinal plants, ethnobotany studies were also carried out on edible plants and pants with other economic uses such as fuel, fodder, timber, etc (Sher 2011; Pegu 2013; Murad et al 2013). This effort is aimed at preserving traditional knowledge or indigenous knowledge, management, utilization, and promoting sustainable livelihoods, food security, and ecosystem services (Yirga 2010; Emiru et al. 2011; Somsri et al 2017). The continuing use of landraces contributes to stable food production and income is a sustainable way to conserve agricultural biodiversity, and local knowledge and community participation are key to successful conservation (Sthapit et al. 2005).

The trend of land-use change from agricultural land to settlement that occurs rapidly in the snake fruit cultivation area is a major threat to both the genetic resources and traditional knowledge. Research that discusses people's perception and appreciation of snake fruit has never been done. In another study on conservation and perceptions of other plants in the South Manobo community in Mindanao, the Philippines found a difference in perception between gender and education. Kindergarten is related to the perception of the importance of biodiversity in Manobos (Salvana and Arnibal 2019). This study aims to determine the value of public perception and appreciation and measure the level of knowledge application of zalacca. These two objectives are used as materials for designing the East Java salak conservation strategy.

\section{MATERIALS AND METHODS}

\section{Study area and sampling}

This research was conducted in 10 areas in East Java, Indonesia. Research areas include Bangkalan, Banyuwangi, Bojonegoro, Jombang, Kediri, Lumajang, Malang City, Malang Regency, Pasuruan, Trenggalek. The ten areas are inhabited by Javanese, Madura, and Pendalungan tribes. The research area map is illustrated using ArcGIS 10.3 (Figure 1).

\section{Methods}

This study was conducted with quantitative survey method. Data collecting was done by purposive and snowball samplings (Naderifar et al. 2017). Respondents were selected based on age, experience, and willingness to respond to the questions. They were divided into four age categories, each consisting of 82 persons. First group consisted of young (17-30 years old), second consisted of adults (31-44 years old), third was a middle-aged group (45-60 years old), and last was an old group (>60 years old). Overall, 328 respondents consisted of 191 males and 136 females responded to the questionnaires or interviews. About $80 \%$ of respondents fulfill the questionnaires while the rest were interviewed in houses, home gardens or yards, and plantations. The content of interview was the same as the questioner. All the information from this research was passed back to the respondent's origin as per their rights protected by law.

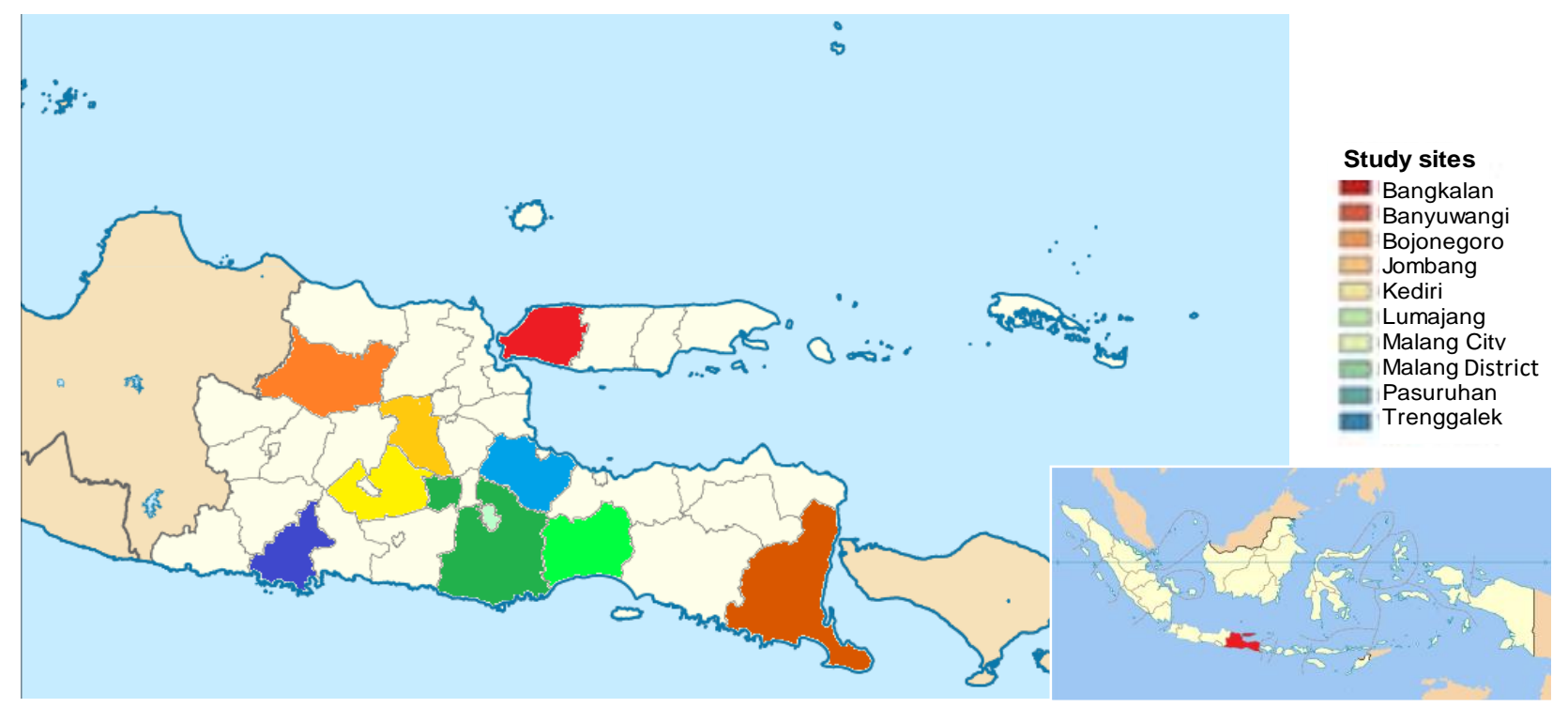

Figure 1. Location of study sited based on snake fruits-producing districts in East Java, Indonesia 
The questionnaire was divided into two sections: (i) the socio-demographic profile of each respondent (e.g., age, gender, and religion); (ii) nine perception questions and thirteen questions of appreciation. Perception questions were about the knowledge on the occurrence of snake fruit, snake fruit local name, snake fruit history, and snake fruit benefits, etc. Thirteen questions about respondent appreciation were related to snake fruit cultivation, replacement of snake fruit plants with other plants, involvement in religious or cultural ceremonies, and the utilizing of snake fruit sustainably.

\section{Data analysis}

Data obtained was in the form of qualitative and quantitative data. Qualitative data were presented descriptively include snake fruit area name, utility, processed food products, and related activities. Quantitative data consists of calculating perception and appreciation of traditional knowledge practice (Hoffman et al. 2007).

Questionnaires were first analyzed for reliability. The reliability tests resulted in an alpha reliability perception value of 0.85 , while it was 0.75 for the appreciation. These values were much larger than the minimum Cronbach alpha 0.7 , perception and appreciation instruments were considered eligible for use as instruments. The answers to the questionnaire were based on choices that corresponded to the level of perception and appreciation of the respondents. The lowest value of 0 (zero) meant that the respondent had the lowest knowledge and the highest possible score was 5 . The values were calculated using the formula 1 resulting in perception/appreciation values (P/A) then grouped into 5 categories, namely Excellent (81-100\%), Good (66-80\%), Simply (51-65\%), Low (31-50\%), and Very Low $(\leq 30 \%)$ (Azrianingsih and Kusumahati 2018).

$$
P=\sum_{i}^{n} \frac{x \cdot k}{n \cdot k^{\text {maks }}} 100 \%
$$

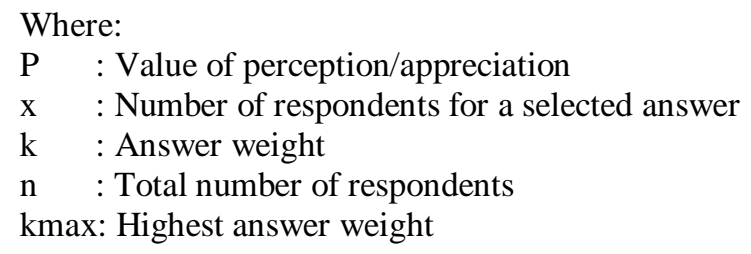

Furthermore, appreciation was analyzed related to ethnobotany which includes knowledge of utility of the fruit. Questions in appreciation were sorted according to the relationship between appreciation and ethnobotany. The knowledge of utility included questions of appreciation on religious or cultural ceremonies/festivals to attract tourist arrivals; to invite other people to plant the snake fruit; to teach others how to process it, and to try getting male flowers so that fruit is beneficial, etc. The analysis used shared similarities with that described by Phillips and Gentry (1993a,b):

$$
\mathrm{Mgj}=\frac{1}{n} \sum \mathrm{Vi}
$$

Where:

Mgj : Average level of knowledge of snake fruit plant utilization owned by members of group $\mathrm{j}$

$\mathrm{Vi}$ : The amount of knowledge of snake fruit plant utilization owned by members $i$ of group $j$ dynamics

j : : Age group

$\mathrm{n} \quad$ : Number of members in group $\mathrm{j}$.

Calculations are continued to measure the changes in knowledge about snake fruit plants. Retention of ethnobotanical knowledge' is the ability of local communities to store, maintain, and retain their knowledge. This retention analysis needs to find out the ethnobotanical knowledge of the East Javanese regarding snake fruit to determine if the knowledge is passed on to the next generation or not using method developed by Zent (2009). This aspect measures retention rate (RG), cumulative retention rate $(\mathrm{RC})$, and annual change rate $(\mathrm{CA})$.

$$
\mathrm{RGt}=\mathrm{Mgt} / \mathrm{Mgr} ; \mathrm{RCt}=\mathrm{RCr} 10^{\log (\mathrm{RGt})} ; \mathrm{CAt}=\mathrm{RCt} / \mathrm{Ygt}
$$

Where:

RGt : Retention rate based on age

Gt : Average local knowledge age group $t$

$\mathrm{Gr}$ : Average age group knowledge $\mathrm{t}+1$

$\mathrm{RCt}$ : Age group cumulative retention rate t;

$\mathrm{RCr}: \mathrm{T}+1$ age group cumulative retention rate

RGt : Age group retention rate

CAt : Age group annual change rate

Ygt : Age group time interval (15 years)

$\mathrm{RCt}$ : Age group cumulative retention rate $\mathrm{t}$.

The last analysis is a one-way ANOVA to determine differences in perception or appreciation between ages and regions. Age differences in the application of traditional knowledge were analyzed using the Wallis Kruskal nonparametric test.

\section{RESULTS AND DISCUSSION}

The level of public knowledge about snake fruit was found to be generally good. Knowledge about local existence (Q1); local name (Q2); benefits (Q4); names of the processed products (Q5); pollination process (Q7); economic importance (Q8); uses (Q9) of snake fruits in other areas had a value above $80 \%$ (Figure 2). Knowledge of snake fruit processing (Q6) had the lowest value (36\%) (Table 1). This level of knowledge did not relate to age. Generally, the level of understanding of people of all ages was above $80 \%$ (Figure 3).

The community knowledge level on snake fruit plants was considered similar among the age. This is due to successful knowledge transfer through generations. Better management practices of snake fruit plants may contribute to the knowledge formation, which may also evolve over time. The value of perception was slightly different between different groups because of individuals' variable attention and interest in the community. Middle-aged paid 
greater attention and showed more interest than young to cultivate snake fruit and use it because they claimed that snake fruit plants were a valuable biological resources for their well-being. Second reason was their long-experience in snake fruit cultivation. This excellent perception may support the conservation of traditional knowledge that has accumulated over generations and local snake fruit in the area.

Snake fruit plantations are passed down through generations. The devolution of snake fruit plantations is followed by the transfer of knowledge from parents to offspring, which is apparent because all age groups have excellent local knowledge, indicative of people interacting with their environment well and wisely. Local knowledge that is passed down through generations becomes a guideline in snake fruit management reaping benefits.

The level of public appreciation of snake fruit was generally quite good. Appreciation regarding providing snake fruits at any time of the year (without waiting for any specific event) (Q4); consuming the fruit (Q6); maintaining snake fruit plantation (Q7); receiving the knowledge of using snake fruits (Q10); receiving knowledge about pollination (Q12), and trying to get male flowers for pollination (Q13) has a value above $80 \%$. Meanwhile, appreciation for processing the fruit and teaching showed the lowest scores (33\% and 37\% respectively) (Figure 4). This level of appreciation appeared to be related to age. In general, the highest appreciation scores were recorded by the middle-aged $(74 \%)$ while the lowest by the younger people (59\%) (Figure 5).

The value of appreciation by age groups over 30 years was categorized as good while the young group fell to a fair level. The age of productive farmers was in the range of 30-60 years. At that age, farmers have the potential to support farming activities, tended to be dynamic, creative, and fast in accepting new technological innovations. Public appreciation was also used to preserve snake fruit crops. All forms of knowledge, beliefs, insights, and habits or ethics lead to human behavior within the community. All forms of knowledge are humanized, practiced, taught, and passed down from generation to generation while forming behavioral patterns towards fellow humans and the nature. People over the 30 years old contribute greatly to preserving snake fruit that can be used as a source of economic income. Snake fruit plants are planted, cared for, and preserved in yards or gardens for survival of the present generation as well as for future generations. Snake fruits represent their knowledge, experience, and spirit. Their knowledge about local values shows this. Local people's perceptions showed that they were very concerned about snake fruit plants. This showed that the adult East Javanese in the study area interacted both in their daily lives, experiences, knowledge, and emotions with the rich biological resources in their environment.

On the other hand, it was observed that the young people (aged 17 to 30 years) were different from their elder groups. In East Java, this age group consisted mostly of students or those with a job outside the region. For example, those aged 17-19 were high school students and those aged 20-24 had student status. If people at that age were not in school, they would have been working outside the region. Therefore, the 17-30 year age group neither undertaken nor been involved in the cultivating or conservation of snake fruit nor understood the concept of local knowledge. Besides, most young have low emotional attachment with local food or a taste for snake fruit, showing minimal interest in its conservation or cultivation.

Table 1. Knowledge level of snake fruit plant utilization in East Java

\begin{tabular}{ccccc}
\hline $\begin{array}{c}\text { Age } \\
\text { category }\end{array}$ & $\begin{array}{c}\text { Knowledge } \\
\text { level of snake } \\
\text { fruit plant } \\
\text { utilization } \\
(\mathbf{M g})\end{array}$ & $\begin{array}{c}\text { Age } \\
\text { retention } \\
\text { rate (RG) }\end{array}$ & $\begin{array}{c}\text { Age } \\
\text { cumulative } \\
\text { retention } \\
\text { rate (RC) }\end{array}$ & $\begin{array}{c}\text { Annual rate } \\
\text { of change } \\
\text { (CA) }\end{array}$ \\
\hline$>60$ & 0.73 & 0.0679 & 0.3322 & -0.045 \\
$45-60$ & 0.95 & 0.0826 & 0.3665 & -0.042 \\
$30-45$ & 0.91 & 0.4764 & 1.07 & 0.0047 \\
$17-30$ & 0.48 & 0.0458 & 0.2741 & -0.048 \\
\hline
\end{tabular}

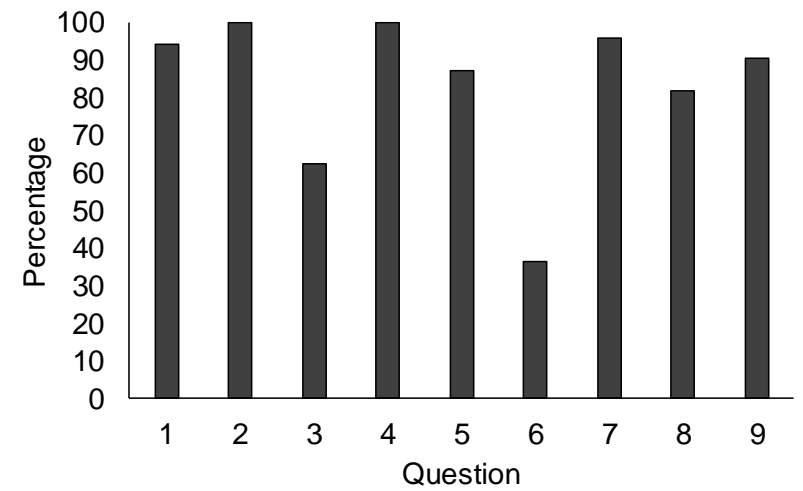

Figure 2. Knowledge of people about the snake fruit, Q1: local existence in this area; Q2: local name; Q3: the history of the existence; Q4: the benefits; Q5: the name of processed product; Q6: processing methods; Q7: pollination process; Q8: economic importance; and Q9: utilization for other purposes. The same letter notation on the variable showed no significant difference in the ANOVA test at $\alpha=0.05$

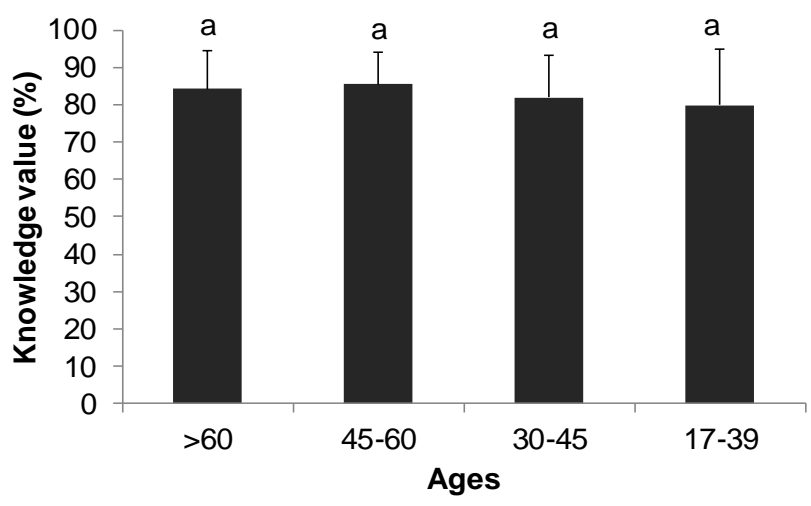

Figure 3. Knowledge values based on age, the same letter notation on the variable showed no significant difference in the ANOVA test at $\alpha=0.05$ 


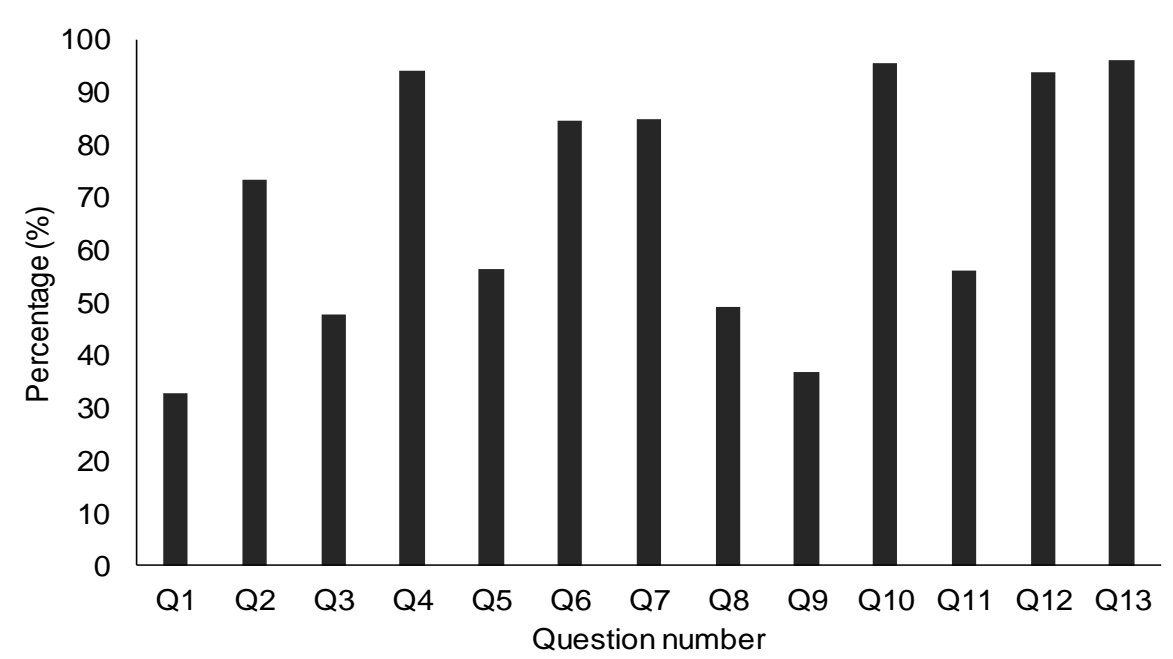

Figure 4. Appreciation of respondents to the snake fruit, Q1: processing foods from the fruits; Q2: replacement with other fruit plants; Q3: use in religious ceremonies; Q4: providing snake fruit all the time (without waiting for the event); Q5: accepting the village government supports to make of processed snake fruits food; Q6: fruit consumption; Q7: maintaining plantation in the village; Q8: inviting others to plant snake fruit; Q9: teaching others to process snake fruits; Q10: receiving the knowledge of using snake fruit; Q11: planting the snake fruits by self; Q12: receiving knowledge about pollination; Q13: trying to get male flowers for pollination, same letter notation on the variable showed no significant difference in the ANOVA test with a significance level of $\alpha=0.05$.

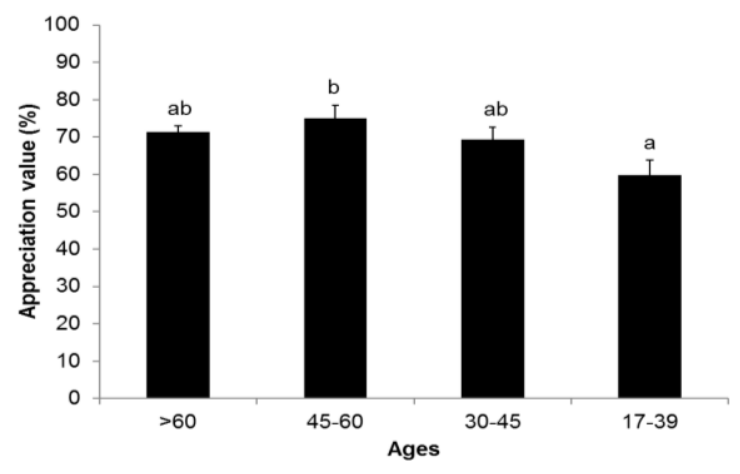

Figure 5. Appreciation values based on age, same letter notation on the variable showed no significant difference in the ANOVA test with a significance level of $\alpha=0.05$.

The trend of land-use change, including snake fruit plantations to settlement areas, has increased rapidly in East Java. Unfortunately, the younger generation supported this situation, which wants to replace their snake fruit plantation with other more profitable crops because of the volatile price of snake fruit. The conversion of snake fruit plantation to other crops or other varieties has threatened local varieties resulting in genetic erosion in snake fruit. For example, variety Kersikan from Pasuruan replaced by other crops, and local snake fruit cultivar from Lumajang was replaced by other cultivars (Pondoh). Although such conversion in Lumajang increased dramatically, some growers continued to maintain their local snake fruit, thus contributing to the conservation of this fruit genetic resources. For example, the local snake fruit planted in the mountainous area of Lumajang.

Although snake fruit plants bear fruit throughout the year, the production peak in certain months. During such months, the price drops and there is a glut in the market. To overcome that problem, farmers try to develop snake fruit to avoid losses in storage and keep the income stable. Unfortunately, farmers' knowledge related to diversification remains inadequate. They need more information on making processed foods i.e. snake fruit jam, sweets, chips, coffee, etc. The application of ethnobotanical knowledge in snake fruit management is an indicator of the development of community experience. The implementation of knowledge can be used to support appreciation (Table 1).

The people of East Java have an average ethnobotanical knowledge application index $(\mathrm{Mg})$ of 0.77 or at a moderate level, based on age, gender, and place of residence, and in this study it was based solely on age factor (Table 1). Kruskal Wallis's $h$ test on age factors showed that each age group had a different level of knowledge. Highly significant differences in knowledge levels between different age groups were observed (even at a p-value of 0.021) and the level of knowledge grew with age of a person. This result corresponded to the value of appreciation in Figure 3. Those in the 17-30 age group had low scores, which was expected. It increased up to a certain age and then declined, probably due to memory factors and other old age-related factors. Knowledge increase could be attributed to experience, intense interaction with snake fruit cultivation and management, its use in daily life, and interaction with outsiders such as tourists.

The dynamics of the application of snake fruit plant and knowledge retention through quantitative analysis of local knowledge increased and then decreased (Table 1). The 1730-year-old age group had low Age retention rate, retention rate, and Annual rate of change scores because of their low interaction with snake fruit and their learning process was ongoing. The age group 30-45 years showed the highest Age retention rate value because they would have interacted with the fruit plant for the longest time and have 
accumulated local knowledge about its cultivation and utilization. A decreased level of knowledge of snake fruit plants' use was noticed as persons grew older, mainly due to memory lapses (Zent 2009). In addition to a decrease in memory, respondents also experienced a decrease in physical activity, which affected the responses to questions during the interview.

A positive annual rate of change value indicates an increase in knowledge, while a negative value indicates a decrease. Negative annual rate of change values occurs at $>60$ years (-0.0045), 45-60 years (-0.0042), and 17-30 years (-0.048). A negative value indicates a decrease in knowledge of the use of snake fruit, a legacy of the East Javanese ancestors. The negative tendency shown by changes in ethnobotanical knowledge between age groups in the East Java community indicates that the process of knowledge inheritance is still going well. Outside influences on an individual can lead to decreased retention of ethnobotanical knowledge, which can result in changes in the level of knowledge (Zent, 2009). The 17-30-year-old is prone to losing knowledge of the use of snake fruit. On the other hand, this age group accumulates knowledge as its experiences increase, for example, interactions with snake fruit. The development and enhancement of knowledge are dynamic and will increase with individuals' experiences (Berk 2017). Other age groups had normal knowledge retention values and less significant knowledge loss. Changes in local knowledge might show a negative trend that occurs between age groups. This indicates the inheritance of knowledge passed down orally. Parents teach about fruit characteristics to their children. The annual rate of change scores decreased except in the 30-45 age group. This indicates a decrease in knowledge of snake fruit utilization that is the legacy of ancestors. Changes in local knowledge indicate a negative tendency that occurs between age groups. This indicates the devolution of knowledge that is passed down orally. Parents teach their children about snake fruit.
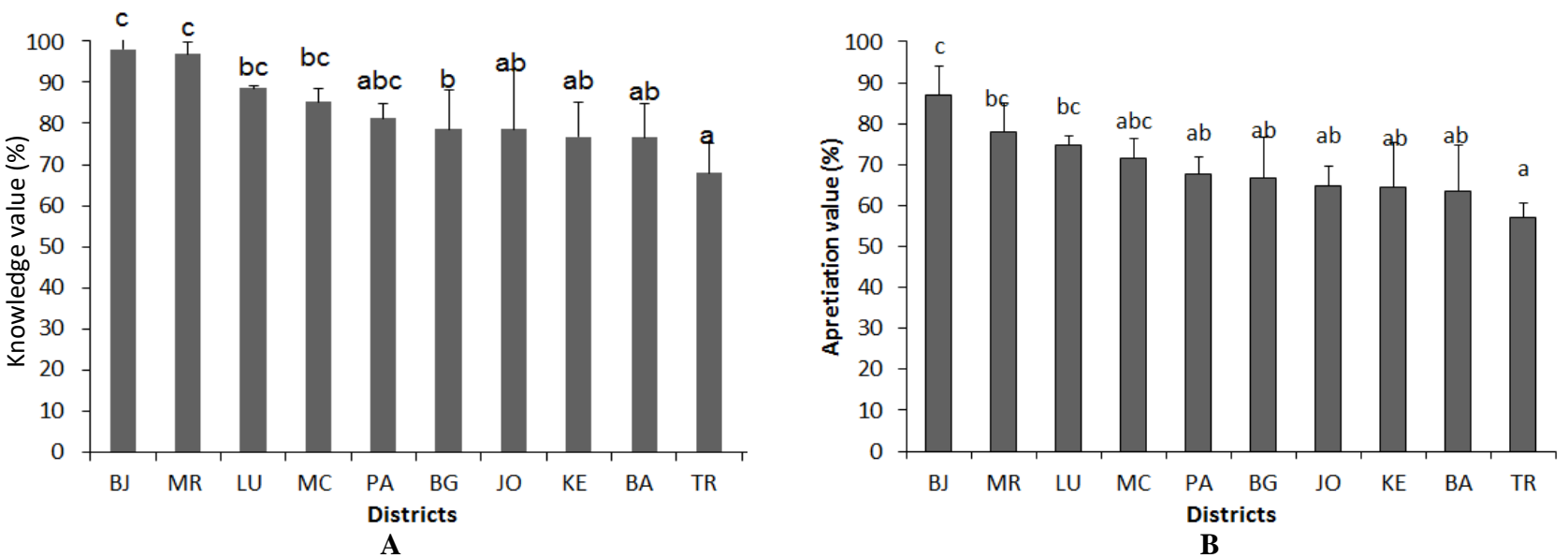

Figure 6. Knowledge (A) and appreciation (B) of respondent from BO: Bojonegoro, MR: Malang Regency, LU: Lumajang, MC: Malang City, PA: Pasuruan, BG: Bangkalan, JO: Jombang, KE: Kediri, BA: Banyuwangi and TR: Trenggalek, different letter notations show a significant difference on the test at the level of $\alpha=0.05$. 
Bojonegoro area grows local snake fruit. In Wedi village, which has a history of snake fruit cultivation, the perception of the community is very good. All the villagers know the history of Wedi snake fruit. All the houses in Wedi village planted local variety, so harvest experienced an abundance of snake fruit at the time of harvest. The abundance of snake fruit is addressed by making processed foods. Snake fruit farmers are becoming snake fruit processed food entrepreneurs. It is interesting to note that the knowledge of Wedi villagers significantly affects their appreciation. Villagers collaborate with the village and local governments to hold snake fruit festivals once a year. The festival aims at (i) introducing a local snake fruit known as snake fruit Wedi; (ii) commemorate Basyir Mujtaba, a public figure, who planted snake fruit seeds in Wedi for the first time. He introduced the snake fruit seeds from Madura to Wedi village; (iii) later started conservation of snake fruit Wedi. Perception and appreciation of Bojonegoro have a great contribution to preserving local snake fruit used as a source of basic needs. Many local communities rely on traditional knowledge and practices in conserving biodiversity and protecting environment. This study shows that the continued cultivation (i.e. one form of conservation through use) of snake fruit and culture are interconnected. The complex relationship between biodiversity conservation and cultural diversity in main centers of cultivation can be used to maintain the conservation of natural resources.

On the contrary, the snake fruit from Trenggalek has a different fate from that of Bojonegoro. The former was not considered as a local cultivar and belonged to Pondoh for a long time. Snake fruit from Trenggalek was cultivated aiming to increase community income. Recently, this fruit encountered a problem of decline due to volatile price in the market, hence the business became less interesting. Some plantation areas were converted to building and settlement areas or replaced by other plant species, such as falcata (for timber) and coconut.

Knowledge of plant diversity is fundamental for its survival. The management and utilization of plant species diversity in each community differ from one area to another. This is due to differences in culture, customs, and the environment of residence. This study recommends three elements of a strategy to promote snake fruit conservation through use: (i) fostering the younger generation to be more creative in processing snake fruit, (ii) increasing the marketing of snake fruit processed products through ecommerce, and (iii) forming a group of snake fruit product lovers in the city with a fair level of knowledge and appreciation. Therefore, community empowerment strategies must be focused on developing and strengthening community knowledge and post-harvest skills to process snake fruit. This empowerment reinforces appreciation and ultimately promotes snake fruit conservation on yards, gardens, and plantations.

The community synergizes with the environment in which snake fruit plants grow to create a sustainable livelihood to meet the community's welfare. Use in religious ceremonies and snake fruit festivals, along with development and marketing of processed foods based on snake fruit, contribute directly or indirectly to snake fruit conservation. People know processed foods well (Q5). However, most people do not yet know how to make processed foods such as snake fruit candy, snake fruit dates, and snake fruit chips (Q 6). Knowledge of processed foods can be obtained through training by relevant agencies (that use knowledgeable locals as well) and by the use of world wide web and internet. The existence of the internet has shifted the focus from newspapers, magazines, and television. People are starting to shift to online media such as social as well as educational medium. Although it is known that the internet can make it easier, the internet has been extensively used as a medium of knowledge transfer in Indonesia. It has only been used as a communication medium or social media. It can now be used to educate the public about snake fruit, its links with people through their culture, and processed foods and their marketing.

In conclusion, this study results reveal that there were variations in the level of knowledge and appreciation between locations and ages. High knowledge and appreciation were found in the middle age, while those in the young generation was the lowest. Those were the highest in location where the people could utilize the fruit for ceremonies or festivals and produce processed food. On the other hand, people with fair level of knowledge and appreciation were found in locations where the conversion of snake fruit plantation land to settlement areas grow rapidly. This study suggests to increase creative processing and marketing of snake fruit, as well as develop snake fruit lovers groups

\section{ACKNOWLEDGEMENTS}

The team would like to thank LPDP for BUDI research funding. Special thanks to all respondents for the valuable contribution to this paper. Our big gratitude to Abdillah, Fauziah, Fauzan, and Setiawan for the field execution assistant, to some colleagues Oktarina, Maulana, M. Yusuf, Lisa Lisdiana, Qomariyah, Yuliani, Gusmalawati, Pahlevi, and Artiono for the valuable discussion related to the completion of this article.

\section{REFERENCES}

Ahmad M, Sultana S, Fazl-i-Hadi S, Hadda TB, Rashid S, Zafar M, Khan MA, Khan MPZ, Yaseen G. 2014. An Ethnobotanical study of Medicinal Plants in high mountainous region of Chail valley (District Swat-Pakistan). J Ethnobiol Ethnomed 10, 36 DOI: 10.1186/17464269-10-36

Awoyemi OK, Ewa EE, Abdulkarim IA, Aduloju AR. 2012. Ethnobotanical assessment of herbal plants in southwestern Nigeria. Acad Res Intl 2: 50-57.

Azrianingsih R, Kusumahati A. 2018. Perception and appreciation of tenggerese of medicinal plants in Wonokitri Village, Tosari Subdistrict, Pasuruan Regency. In: Siswanto D, Mastuti R, Huyop FZ, Treesubsuntorn C (eds.). Proceeding of the 9th International Conference on Global Resource Conservation (ICGRC) and AJI from Ritsumeikan University. Universitas Brawijaya, Malang, 7-8 March 2018.

Berk LE. 2017. Development Through the Lifespan. 7th ed. Pearson, USA. 
Dransfield J. 2009. A new species of Salacca from Sarawak. Palms 53 : $167-170$.

Elfrida, Mubarak A, Suwardi AB. 2020.The fruit plant species diversity in the home gardens and their contribution to the livelihood of communities in rural areas. Biodiversitas 21 (8): 3670-3675.

Emiru B, Ermias A, Wolde M, Degitu E. 2011. Management, use, and ecology of medicinal plants in the degraded drylands of Tigray, Northern Ethiopia. J Hortic For 3 (2): 32-41.

Henderson, J. 2008. A new species of Salacca (Palmae) from Southeas Asia. Bull Mak Bot Garden 7: 87-92.

Jaisankar J, Velmurugan A, Sivaperuman C. 2018. Biodiversity Conservation: Issues and strategies from the tropical Islands. In Biodivers Clim Change Adapt Trop Isl. Academic Press, New York.

Kantati YT, Kodjo KM, Dogbeavou KS, Vaudry D, Leprince J, Gbeassor M. 2016. Ethnopharmacological survey of plant species used in folk medicine against central nervous system disorders in Togo. J Ethnopharmacol 181: 214-220. DOI: 10.1016/j.jep.2016.02.006.

Khruomo N, Deb CR. 2018. Indigenous wild edible fruits: sustainable resources for food, medicine and income generation-A study from Nagaland, India. J Exp Biol Agric Sci 6 (2): 405-413.

Mabaya E, Jackson J, Ruethling G, Carter CM, Castle J. 2014. Wild fruits of Africa: Commercializing natural products to improve rura livelihoods in southern Africa. Intl Food Agribus Man 17B (B): 69-74

Murad W, Azizullah A, Adnan M, Akash T, Saqib W, Ashfaq A. 2013 Ethnobotanical assessment of plant resources of Banda Daud Shah, District Karak, Pakistan. J Ethnobiol Ethnomed 9: 77. DOI 10.1186/1746-4269-9-77

Naderifar M, Goli H, Ghakjaie F. 2017. Snowball sampling: A purposeful method of sampling in qualitative research. Strides Dev Med Educat 14 (3): e67670. DOI: 10.5812/sdme.67670.

Pegu R, Gogoi J, Tamuli AK, Teron R. 2013. Ethnobotanical study of Wild Edible Plants in Poba Reserved Forest, Assam, India: Multiple functions and implications for conservation. Res J Agric Fores Sci 1 (3): $1-10$.

Phillips O, Gentry AH. 1993a. The useful plants of Tambopata. Peru. I. Statistical hypothesis tests with a new quantitative technique. Econ Bot 47 (1): 15-32.

Phillips O, Gentry AH. 1993b. The useful plants of Tambopata. Peru. II. Additional hypothesis testing in quantitative ethnobotany. Econ Bot 47 (1): $33-43$.

Purwanto, SR, Novenda IL, Narulita E. 2020. Ethnobiology study on nature and processing plants and animals in traditional sea-picking of Banyuwangi Regency. Mangifera Educat 5: 38-54. 10.31943/mangiferaedu.v5i1.90.

Russell J, Yates CP, Edwards AC, Whitehead PJ, Murphy BP, Lawes MJ. 2015. Deriving multiple benefits from carbon market-based savanna fire management: An Australian example. PLoS One 10 (12): e0143426. DOI: 10.1371/journal.pone.0143426.

Saleh M, Siddiqui MJ, Mediani A, Hadiani N, Ahmed QU, Zaiton MS, Said-Besbes S. 2018. Salacca zalacca: A short review of palm botany, pharmacological uses, and phytochemistry. Asian Pac J Trop Med 11 (12): 645-652.
Salvana FRP, Arnibal SL. 2019. Importance of indigenous communities' knowledge and perception in achieving biodiversity conservation: A case study from Manobo tribe of Southern Mindanao, Philippines. Asian J Ethnobiol. 2 (2): 54-61.

Sher Z, Khan ZUD, Hussain F. 2011. Ethnobotanical studies of some plants of Chagaharzai valley, District Buner, Pakistan. Pak J Bot 43 (3): $1445-1452$.

Silalahi S, Nisyawati. 2018. The ethnobotanical study of edible and medicinal plants in the home garden of Batak Karo sub-ethnic in North Sumatra, Indonesia. Biodiversitas 19 (1): 229-238.

Somsri S, Yoovatana M, Noppornphan C, Sangudom T, Palakorn K, Prasongsup S, Sripinta P, Posawang S, Nimkingrat T, Rukkhaphan A, Siriyan R, Changprasert S, Tongtao S, Dum-ampai N, Ariyapuchai S, Issarakraisila M, Changtragoon S, Rungrattanakul P. 2017. Conservation and sustainable use of cultivated and wild tropical fruit diversity: promoting sustainable livelihoods, food security and ecosystem services. Acta Hortic. 1186: 69-76 DOI: 10.17660/ActaHortic.2017.1186.11

Sthapit B, Ramanatha Rao V, Jarvis D. 2005. In situ conservation of coconut diversity. In: Batugal PA, Ramanatha Rao V, Jeffrey O (eds.). Coconut Genetic Resources. IPGRI-APO, Serdang.

Suica-Bunghez IR, Teodoresc S, Dulama ID, Voinea OC, Simionescu S, Ion RM. 2016. Antioxidant activity and phytochemical compounds of snake fruit (Salacca zalacca). IOP Conf Ser Mater Sci Eng 133: 012051. doi:10.1088/1757-899X/133/1/012051.

Sutraningsih NKA, Sukenti K, Sukiman, Aryanti E. 2019. Ethnobotanical study on Daksina constituent plants on Lombok Island, West Nusa Tenggara, Indonesia. Asian J Ethnobiol 2 (2): 48-53.

Suwardi AB, Navia ZI, Harmawan T, Syamsuardi, Mukhtar E. 2020b. Ethnobotany and conservation of indigenous edible fruit plants in South Aceh, Indonesia. Biodiversitas 21 (5): 1850-186.

Tura TT, Soromess T, Argaw M, Leta S. 2017. Holy hills role in biodiversity conservation and mountain management: implication of multi-purpose Ethiopian Orthodox Tewahido Church in sustainable mountain conservation. J Biodivers Environ Sci 1: 179. DOI: $10.4172 / 2332-2543.1000179$

Wakhidah A, Silalahi M, Pradana DH. 2017. Inventory and conservation plant of oke sou traditional ceremony; A welcoming tradition of maturity girl on the community of Lako Akediri Village, West Halmahera, Indonesia. Biodiversitas 18 (1): 65-72.

Widiyastuti Y, Kusumadewi AP, Sutjipto. 1998. Several Kinds of Plants Used in Traditional Ceremonies Sekaten in Kasunanan, Surakarta. Prosiding Seminar Nasional Etnobotani III, Denpasar. [Indonesian]

Yirga G. 2010. Assessment of indigenous knowledge of medicinal plants in Central zone of Tigray, Northern Ethiopia. Afr J Plant Sci 4: 6-11.

Zent S. 2009. Methodology for developing a vitality index of traditional environmental knowledge (vitex) for the project "Global indicators of the status and trends of linguistic diversity and traditional knowledge". Centro de Antropologia Instituto Venezolano de Investigaciones Cientificas (IVIC), Venezuela. 